\title{
Prevalence of alopecia in gray seals Halichoerus grypus atlantica in Massachusetts, USA, 2004-2013
}

\author{
Katie Pugliares-Bonner ${ }^{1, *}$, Katherine McKenna ${ }^{1,2,3}$, Lisa $_{\text {Sette }}{ }^{4}$, Misty Niemeyer $^{2}$, \\ Michael Tlusty ${ }^{5,6}$ \\ ${ }^{1}$ Rescue and Rehabilitation Department, New England Aquarium, Boston, MA 02110, USA \\ ${ }^{2}$ Marine Mammal Rescue and Research, International Fund for Animal Welfare, Yarmouthport, MA 02675, USA \\ ${ }^{3}$ National Marine Life Center, Bourne, MA 02532, USA \\ ${ }^{4}$ Marine Animal Entanglement Response, Center for Coastal Studies, Provincetown, MA 02657, USA \\ ${ }^{5}$ Anderson Cabot Center for Ocean Life, New England Aquarium, Boston, MA 02110, USA \\ ${ }^{6}$ School for the Environment, University of Massachusetts Boston, Boston, MA 02125, USA
}

\begin{abstract}
There has been an increase in the presence of alopecia among gray seals Halichoerus grypus atlantica in Massachusetts, USA. To understand the prevalence and describe the presentation of this condition, data records and photographs of 10070 gray seals from 2004-2013 were reviewed; there were sufficient data to confidently assess the presence or absence of alopecia in 2134 seals. Mild hair loss presented in multifocal patches with minimal to no skin lesions or erythema. In severe cases, alopecia was concentrated over the dorsal head, neck, and shoulders and extended down the ventrum, affecting $>50 \%$ of the body. Associated skin lesions and erythema were often present. Alopecia was documented in $7.1 \%$ of the surveyed seals, and was centered in Nantucket. Alopecia was more prevalent in stranded/sighted animals in spring and summer, with $81 \%$ of cases documented from April to July. There was no sex bias, and weanlings were the most affected age class (38\%). The etiology for alopecia in Massachusetts gray seals is unknown. Possible causes of alopecia in wildlife are infectious disease, nutritional deficiencies, endocrinopathies, or chronic physiologic stress. High population density around Nantucket may escalate intraspecific competition for resources, which may indirectly lead to stress-induced immunosuppression or nutritional deficiencies. Crowded haul-out sites increase the opportunity for disease transmission. The weanling age class may be prone to alopecia due to naïve immune systems and inexperienced foraging capabilities. Diagnostic sample collection from gray seals will be required to characterize the etiology, pathogenesis, and significance of alopecia in this population.
\end{abstract}

KEY WORDS: Hair loss $\cdot$ Phocid $\cdot$ Pinniped $\cdot$ New England

\section{INTRODUCTION}

Alopecia is a condition characterized by focal hair loss that can vary in severity. It has been documented in a wide variety of mammals including wild, domesticated, and laboratory animals (Pier et al. 2000, Bildfell et al. 2004, Costello et al. 2006, Novak \& Meyer 2009, Bello-Gutiérrez et al. 2010, Lynch et al. 2011, Madslien et al. 2011, Atwood et al. 2015). This condition is often multifactorial and has been associated

${ }^{*}$ Corresponding author: kpugliares@neaq.org with an assortment of causes, including ectoparasites (Bildfell et al. 2004, Madslien et al. 2011), fungal dermatitis (Pier et al. 2000, Barnett et al. 2011), bacterial (Mannan et al. 2009) or viral agents (KennedyStoskopf et al. 1986, Lipscomb et al. 2001), nutritional deficiencies or toxicities (Frank 1998, Rushton 2002, Novak \& Meyer 2009, Lynch et al. 2012, Pedersen et al. 2012), hormonal imbalances and/or stress (Pedersen et al. 2012, Novak et al. 2014), allergens (Novak \& Meyer 2009, Jensen-Jarolim et al. 2015), seasonal Attribution Licence. Use, distribution and reproduction are unrestricted. Authors and original publication must be credited. 
factors, and senescence (Novak \& Meyer 2009, Tang et al. 2012), among others.

Mammals are homeotherms, with most species relying on fur for thermoregulation. Fur is a major adaptation that provides insulation and reduces the flow of heat from the animal to its environment (Costa \& Kooyman 1982, Watts et al. 1993). The functional morphology of fur varies among marine mammals; in some species fur is the primary insulator while others have developed secondary means of thermoregulation (Liwanag et al. 2012). Phocids are semi-aquatic and spend substantial time on shore to rest, breed, and pup. They rely on a thick blubber layer for insulation and the manipulation of the arteriovenous anastomoses of the skin for thermoregulation when in water. The importance of fur in total insulation while submerged is negligible (Liwanag et al. 2012). However, fur makes a considerable contribution to total insulation for phocids while exposed to air. Kvadsheim \& Aarseth (2002) estimated that phocid fur contributes to $30 \%$ of thermal insulation in air and, with removal of this adaptation, individuals would require a $40 \%$ increase in metabolic rate to compensate for heat loss. The guard and under-hairs are shortened in phocids and lack the interlocking pattern exhibited by more thickly furred animals such as sea otters and fur seals, suggesting that phocid fur is utilized more for streamlining and drag reduction than for insulation while in water (Liwanag et al. 2012).

The loss of fur can have cumulative negative effects leading to many health problems. The decrease in thermoregulatory and drag reduction properties of the fur can lead to an increase in metabolic rate to compensate for heat loss, and a change in energy requirements. If an animal is not able to augment its diet in response to these changes, this can lead to an eventual decline in nutritional condition (Rosen et al. 2007). Poor nutritional condition can cause an individual to be more susceptible to infectious disease, leading to significant morbidity or mortality (Trites \& Donnelly 2003, Bowen et al. 2015). Alternatively, the presence of alopecia can be an indicator of an underlying autoimmune or infectious disease process (Novak \& Meyer 2009, Bowen et al. 2015).

Over the past decade, alopecia has been observed in gray seals Halichoerus grypus atlantica with increasing regularity along the coast of Massachusetts, which is the center of gray seal abundance in United States (US) waters (Waring et al. 2016). These seals are part of the Western North Atlantic (WNA) gray seal population observed year-round from New Jersey, US, north toward Labrador, Canada (Wood et al. 2011, Waring et al. 2016). By the mid- $20^{\text {th }}$ century, this population was almost completely extirpated from northeastern US waters when gray seals were hunted for a bounty in the US and culled in Canadian waters (Andrews \& Mott 1967). With State and Federal protection in the US, in 1965 and 1972 respectively, and reduced culling in Canada during the 1980s, the number of gray seals in the Gulf of Maine has since grown significantly (Rough 1995, Lelli et al. 2009). There are 2 long-established, large breeding colonies in Canada: Sable Island, Halifax, Nova Scotia and in the Gulf of St. Lawrence on pack ice (Bowen et al. 2003). As recently as the 1990s, recolonization of the Canadian gray seal has occurred within the northeastern US (Wood et al. 2011, Waring et al. 2016), with the establishment of thriving pupping and breeding sites on South Monomoy Island and Muskeget Island off of Cape Cod, Massachusetts (Rough 1995, Waring et al. 2016). The pupping rate on Muskeget Island has increased exponentially over the past 2 decades, with 5 pups observed at this site in 1988 and 2095 pups observed during the 20072008 breeding season (Rough 1995, Waring et al. 2016). The most recent maximum count for gray seals in southeastern Massachusetts was 15756 in 2011, which suggests an estimated annual increase of $8.6 \%$ from 1999-2011, likely due to both natural population growth and immigration from Canada (Waring et al. 2016). From May to June, WNA gray seals undergo an annual molt, an energetically costly process in which seals shed their old fur as a new coat grows in its place (Murie \& Lavigne 1992, Boily \& Lavigne 1996). Exposure of bare skin is not expected during a successful molt. However, along the coastal northeastern US, many live gray seals have been observed throughout the year with complete hair loss at varying degrees of severity and no observable new hair growth. The etiology of alopecia in gray seals is currently unknown.

The goal of this study was to describe the clinical presentation and determine prevalence of alopecia in gray seals observed in Massachusetts. We analyzed data from marine mammal stranding organizations in combination with survey photos of known seal haul-out sites to estimate prevalence by demographic class as well as prevalence over spatial and temporal variation. Marine mammals are considered ecosystem sentinels, and the emergence of an alopecia syndrome may be an indicator of an ecological or biological disturbance in the marine environment, which is a highly valuable economic resource for the coastal states of the northeast US. Understanding the prevalence and significance of alopecia in gray seals observed in Massachusetts will hopefully lead to 
further investigation into etiology of the condition, which may have implications for understanding seal population health.

\section{MATERIALS AND METHODS}

\section{Stranded/sighted data}

A total of 995 reports of both live and dead gray seals Halichoerus grypus atlantica observed along the shoreline of Massachusetts from 2004-2013 were examined. During the study period, there were no gaps in coverage for stranding response in the study area as personnel were available to respond to reports $24 \mathrm{~h} \mathrm{~d}^{-1}, 365 \mathrm{~d} \mathrm{yr}^{-1}$. Stranded animal records included confirmed unique reports of carcasses or living seals that were unable to return to their natural behavior or habitat and required human intervention. Sighted animal records included confirmed reports of living seals on shore that did not require human intervention and were only monitored by stranding network biologists until returning to the water. Body length and age data published in McLaren (1993) were used in combination with age and sexual maturity data published in Hammill \& Gosselin (1995) to categorize animals by age class. For most cases, age class was assigned using measured or estimated body size in relation to the breeding/ pupping season. For the cases that received a complete post-mortem exam, age class was confirmed through gross or histological examination of the reproductive organs. Gray seals in Massachusetts typically pup throughout the month of January (Wood et al. 2007). Maternally dependent pups are born with a full lanugo coat and do not shed this white coat until weaned (Kovacs \& Lavigne 1986). Dependent pups with lanugo were not considered in our assessment. Individuals examined from February-October with an actual or estimated straight body length $<125.0 \mathrm{~cm}$ were categorized as weanlings. Males with an actual or estimated straight body length $>200.0 \mathrm{~cm}$ and females with an actual or estimated body length $>175.0 \mathrm{~cm}$ were classified as reproductively mature. All others were categorized as immature. Sex was determined by visualization of sex differences in pelage pattern (Reeves et al. 2002).

\section{Seal haul-out survey data}

One of 4 established seasonal gray seal haul-out sites on Cape Cod, Massachusetts (Head of the Mea- dow, Truro; High Head, Truro; Chatham Harbor, Chatham; and South Monomoy, Chatham) was photographed on a single day between the 10th and 20th day of each month from May to October. A total of 23 surveys were conducted between 2008 and 2013. All surveys were completed between sunrise and sunset on either side of low tide to capture the greatest number of seals hauled out during the lowest point in the tide cycle. Survey effort varied minimally over the study period with the majority of the effort taking place between June and September, and conducted by the same staff. Any variations in effort were due to weather and sea conditions. The High Head haul-out site was the most frequently surveyed site $(\mathrm{n}=12)$, followed by Chatham Harbor $(n=5)$, Head of the Meadow $(n=3)$, and South Monomoy $(n=3)$. Photographs at the Chatham sites were taken from a vessel while photographs at the Truro sites were taken from land approximately $45 \mathrm{~m}$ (150 feet) away from the haul-out using a Canon 5D or 7D digital camera and 100-400 mm zoom lens. Photographs of the entire haul-out site were taken during multiple passes by the site during a single survey effort. For each survey date, the single pass that documented the most number of seals with the best quality images was selected for analysis. Utilizing images from a single pass of 1 haul-out site $\mathrm{mo}^{-1}$ decreased the possibility of double counting alopecia-positive individuals. Images of 9075 animals were reviewed.

\section{Defining degree of alopecia}

Data records (i.e. phone logs, health assessments, necropsy reports) and photographs were used to assess degree of alopecia. Hair loss due to scarring from healed human interaction (entanglements and vessel strikes) or natural wounds (conspecific, shark bites, and canid wounds) was not classified as alopecia for the purpose of this study. Mild alopecia was defined as one small/medium patch $(<10.0 \mathrm{~cm}$ diameter) or a few smaller patches of complete hair loss that affected $<10 \%$ of the animal (Fig. 1). Minimal associated irritation was rarely present. Moderate alopecia was defined as complete hair loss at one larger focal area or over multiple areas of the body that affected $10-50 \%$ of the animal (Fig. 2). Associated irritation or lesions were occasionally present. Severe alopecia was defined as complete hair loss over multiple areas of the body that affected $>50 \%$ of the animal (Fig. 3). Associated irritation or lesions were usually present. If alopecia was mentioned on the necropsy report or health assessment sheet but 

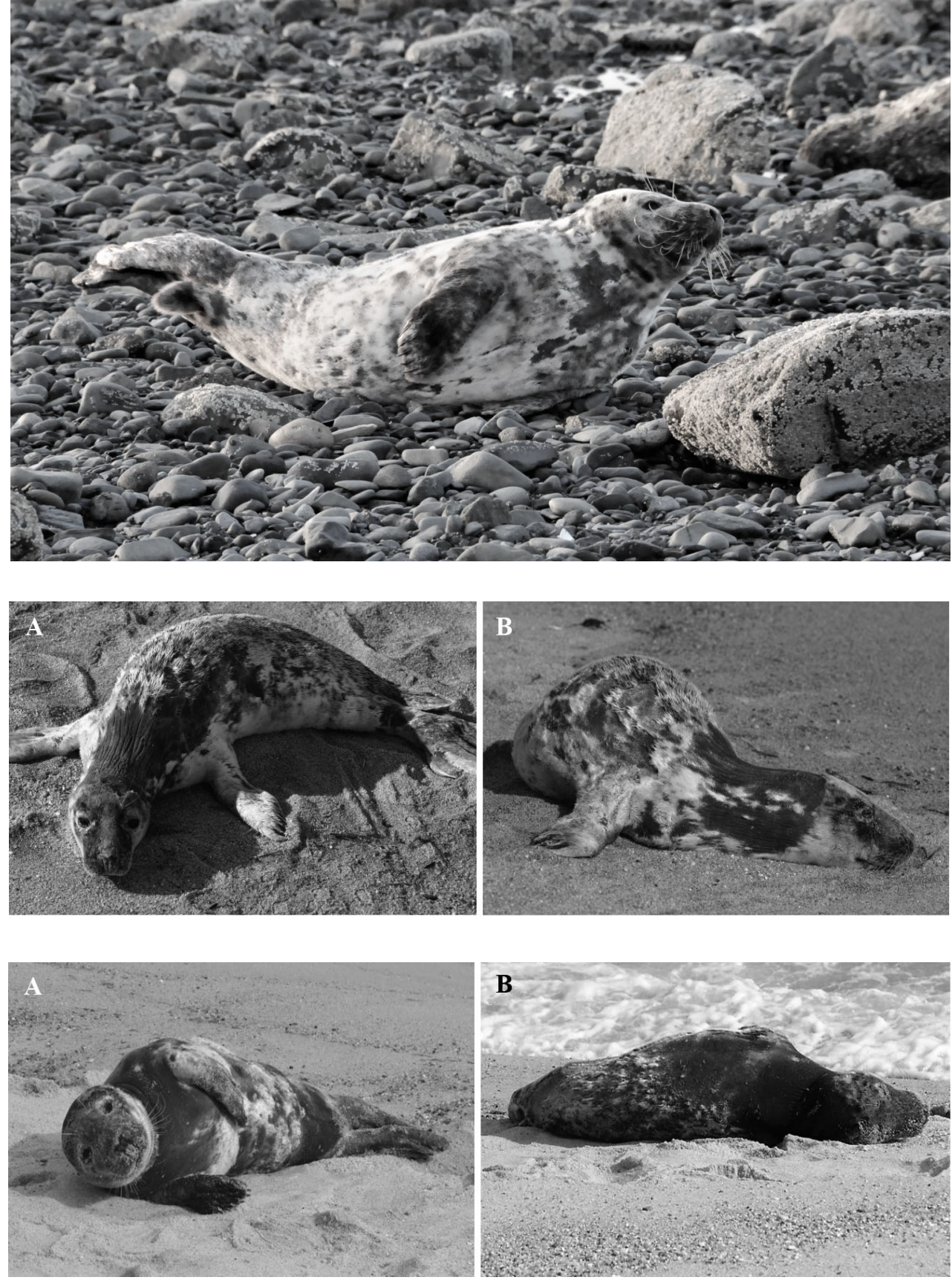

Fig. 1. Gray seal weanling with mild alopecia: one small/medium patch $(<10.0$ $\mathrm{cm}$ diameter) or multiple smaller patches of complete hair loss that affected $<10 \%$ of the animal

Fig. 2. $(\mathrm{A}, \mathrm{B})$ Gray seal weanling with moderate alopecia: complete hair loss at one larger focal area or over multiple areas of the body that affected 10-50\% of the animal. Associated irritation or lesions were occasionally present

Fig. 3. $(\mathrm{A}, \mathrm{B})$ Gray seal weanling with severe alopecia: complete hair loss over multiple areas of the body which affected $>50 \%$ of the animal. Associated irritation or lesions were usually present was not quantified, this was categorized as 'Present/ unspecified'. Animals that had photos showing 3 or more surfaces of the body (dorsum, ventrum, right flank, left flank, and head/neck) or had a complete external exam by marine mammal stranding biologists but lacked evidence of alopecia were categorized as 'None'. If decomposition or scavenger damage to a dead animal prohibited a confident assessment or if photo documentation was not of sufficient quality, then alopecia was categorized as
'Could not be determined' or 'CBD'. If a thorough exam was conducted on the animal (i.e. complete necropsy or health assessment by a biologist) and alopecia was not assessed (field left blank) then this was categorized as 'Not determined' or 'ND'. Positive alopecia cases were plotted on a map constructed using ArcGIS software (ArcMap ${ }^{\mathrm{TM}}$ 10.3.1; ESRI) and data layers from both the Office of Geographic Information (MassGIS), Commonwealth of Massachusetts, and Natural Earth. 


\section{Statistical analysis}

Demographic data for all individuals as well as report date, latitude-longitude, and animal disposition were compared for the presence or absence of alopecia. Given the proximity of the 2 haul-out sites in Truro and 2 sites in Chatham, data were grouped by town for statistical analysis involving the haul-out sites. Comparisons were tested with a $\chi^{2}$ test (Real Statistics Resource Pack software release 4.3; Zaiontz 2015).

\section{RESULTS}

Of the 995 stranded/sighted records and images of 9075 animals at haul-out sites reviewed, we were able to confidently assess the pelage of 2134 individuals (364 of 995 stranded/sighted and 1770 of 9075 haul-outs). Mature individuals made up the largest fraction (67\%) of the data set, while immature and weanlings were less than a quarter each (18 and 14\%, respectively). Sex was represented almost equally; $50.2 \%$ of individuals were male and $48.6 \%$ female, with the sex ratio equivalent across both the stranded/sighted and haul-out data sets. Sex was not determined in the remaining $1.2 \%$. Weanlings comprised a majority of the stranded/ sighted observations $(72 \%)$, while haul-out data included mostly mature animals $(79 \%)$.

Of the 2134 gray seals Halichoerus grypus atlantica with enough data to determine presence or absence of alopecia, $7.1 \%$ had some degree of hair loss. Severity of alopecia was similar across all categories, with $25 \%$ exhibiting mild, $32 \%$ moderate, $20 \%$ severe, and the remainder having alopecia but severity was not determined. For the moderate to severe cases, alopecia was most commonly appreciated around the shoulders and neck and extended toward the dorsal head. Alopecia was observed in $34 \%$ of the stranded/sighted re- cords, and only $1.5 \%$ of the haul-out sightings $\left(\chi^{2}=\right.$ $93.9, \mathrm{p}<0.001)$, with the majority of the observations $(82 \%)$ documented in living seals. Weanlings were the most affected age class (38\% affected), whereas $6 \%$ of immature and $1 \%$ of mature animals had alopecia $\left(\chi^{2}=513.9, p<0.001\right)$. Observations of alopecia in males and females occurred at a similar rate $(7.4 \%$ of males vs $6.0 \%$ of females).

Alopecia was documented most commonly in stranded/sighted individuals around Nantucket, Massachusetts, and almost proportionately equal at both haul-out sites (1.5 and 1.65\%; Fig. 4). The

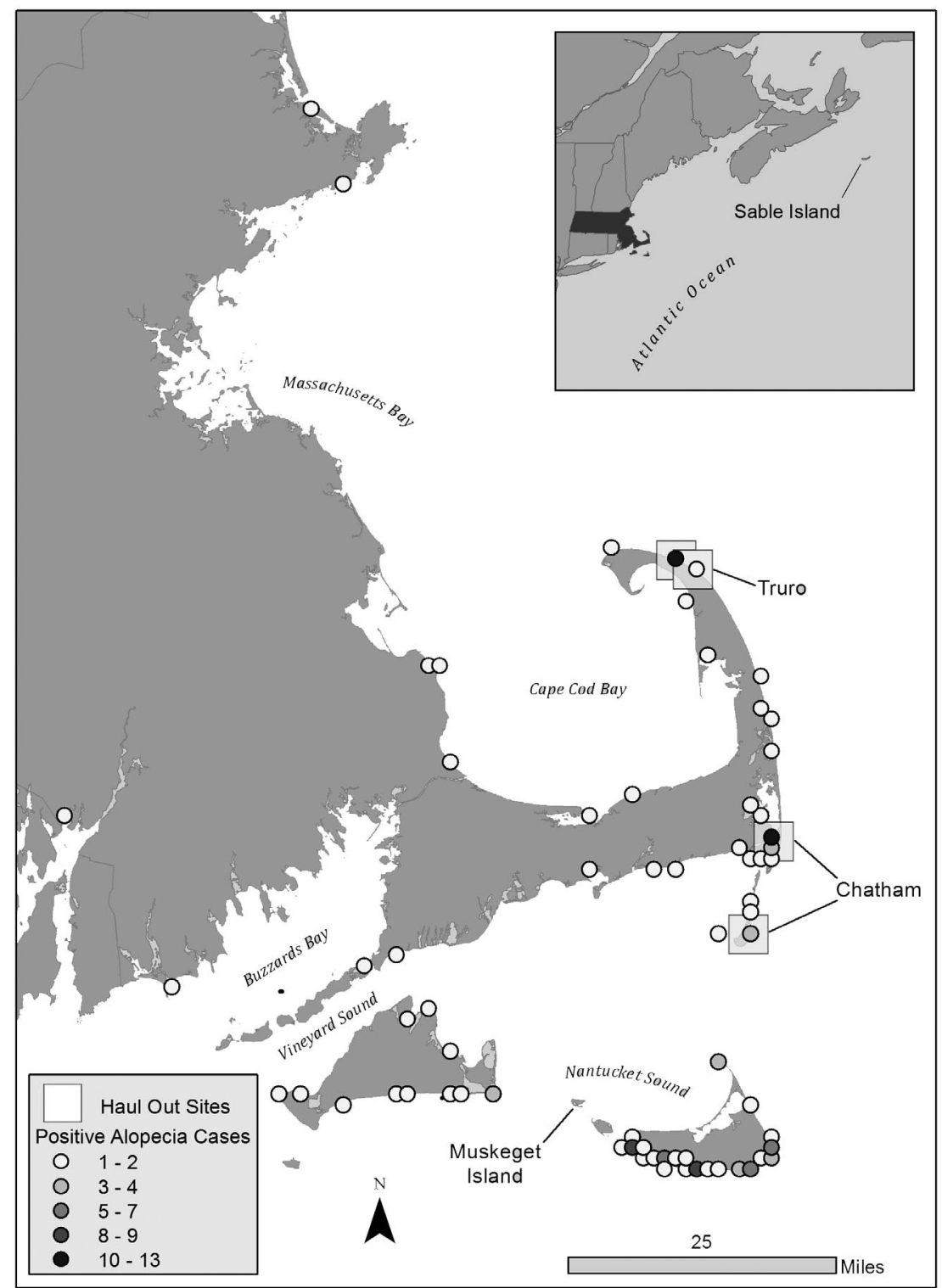

Fig. 4. Hair loss was documented most commonly in stranded/sighted gray seal individuals around Nantucket, Massachusetts, while hair loss was documented almost proportionately equal at both haul-out sites. Dots: gray seals with alopecia; boxes: surveyed haul-out sites 
stranded/sighted data represent 10 consecutive years of observations throughout all months of the year, whereas the surveys at the haul-out sites took place over 6 consecutive years between the months of May and October. Due to this disparity in reporting, the data sets were examined separately when prevalence was evaluated on a temporal or seasonal scale. For the stranded/sighted data, the number of alopecia cases not only increased over time, but the percentage of stranded/sighted animals with alopecia per year increased as well (Fig. 5). Although hair loss was documented in stranded/sighted gray seals during all months of the year, the majority of cases (81\%) were observed in the months April through July with a peak in May ( $\mathrm{n}=34$; Fig. 6). Over the 6 yr that surveys at the haul-out sites took place (2008-2013), the average number of observed cases annually was 4.5, with a maximum of 13 in 2012. Most cases were observed in August (52\%).

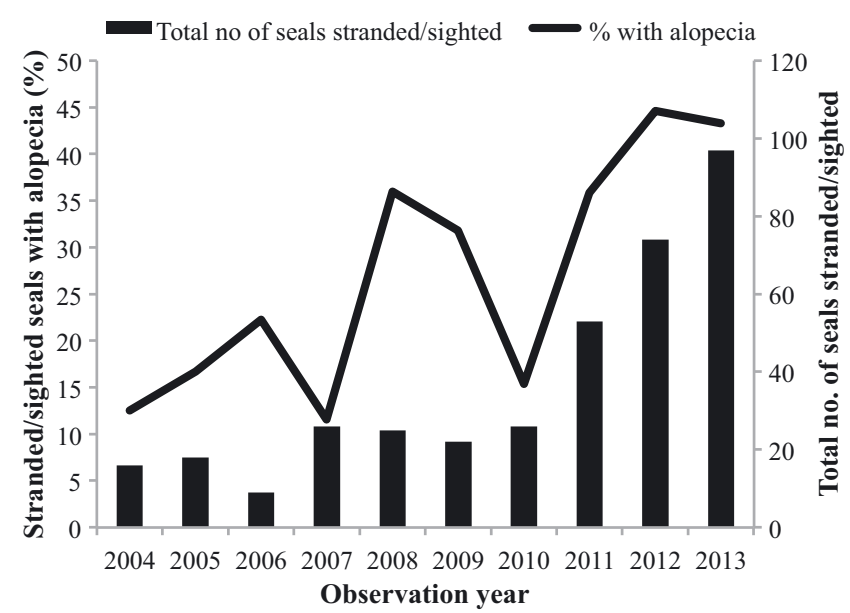

Fig. 5. Annual number of reported stranded/sighted gray seals and percentage of stranded/sighted seals observed with alopecia from 2004-2013. A total of 364 stranded/ sighted seals were confidently assessed for alopecia

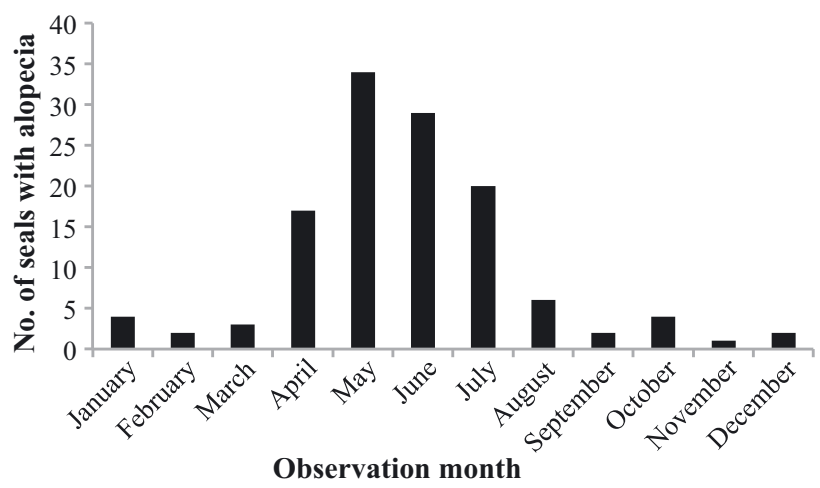

Fig. 6. Seasonal distribution of alopecia observations in stranded/ sighted gray seals

\section{DISCUSSION}

Alopecia appears to be an emerging health issue within the NWA gray seal Halichoerus grypus atlantica population, with $7.1 \%$ of the 2134 seals examined in Massachusetts showing signs of alopecia and the number of incidences increasing over time. Alopecia was more prevalent in living seals, suggesting this condition is not associated with imminent mortality. However, alopecia in a typically furred animal can lead not only to a decline in health of the individual, but the presence of alopecia can also be an indicator of an underlying autoimmune or infectious disease process (Novak \& Meyer 2009, Bowen et al. 2015). It is important to understand the demographics of disease in order to effectively begin an investigation into etiology. Alopecia in gray seals did not appear to be sex-specific, but it did appear to affect weanlings more significantly than any other age group. Hair loss was observed throughout all months of the year; however, there appeared to be a seasonal link, with the majority of observations taking place from AprilJuly. Observations of the condition centered in Nantucket and Chatham, which was expected due to the high density of gray seals in these areas.

\section{A factor of age class}

Weanlings were the most affected age class. Various degrees of alopecia severity observed in this age class could not be considered a disruption of a normal molt because gray seal pups do not enter their first true annual molt until the following year (Noren et al. 2008). The only form of hair loss this age class should experience is shedding of their natal lanugo following the abrupt cessation of nursing (Bowen et al. 2006, Noren et al. 2008). Gray seal pups are typically born in Massachusetts throughout January and exclusively nurse for about $3 \mathrm{wk}$ postparturition (Bowen et al. 2006, Wood et al. 2007, Noren et al. 2008). Therefore, the number of $<1 \mathrm{yr}$ old gray seals observed with alopecia was highly unexpected.

It is possible that the naïve immune system of weanling seals increased their susceptibility to infectious diseases, some of which may have alopecia as a secondary sign (Duignan et al. 2014). Varying degrees of alopecia have been associated with infectious agents such as a retrovirus in California sea lions Zalophus californianus (Kennedy-Stoskopf et al. 1986) and morbillivirus in juvenile harp Pagophilus groenlandicus and hooded seals Cystophora cristata (Lip- 
scomb et al. 2001). Retroviruses have yet to be identified in WNA gray seals. However, morbillivirus, particularly phocine distemper virus, is a pathogen that frequently circulates enzootically through this population as well as other WNA seal species (Duignan et al. 1995, 2014, Bogomolni et al. 2010, A. Bogomolni unpubl. data). Sample collection and analysis for morbillivirus exposure and infection specifically from gray seal weanlings with and without alopecia would be informative.

Seal lice (Echinophthiriidae) and mites (Demodecidae) are common in many pinniped species, and heavy burdens of these ectoparasites lead to skin irritation and eventually alopecia (Thompson et al. 1998, Izdebska \& Rolbiecki 2010). Ectoparasite burdens can vary with age due to the differences in intraspecific behavior and stages of immune system development characteristic of each age class (Thompson et al. 1998). The prevalence of ectoparasites in gray seals in Massachusetts has yet to be assessed and would be an informative investigation toward understanding the cause of alopecia syndrome in this population.

Another age-related factor that might contribute to the high prevalence of alopecia among gray seal weanlings in Massachusetts is related to diet and diving abilities characteristic of this age class. Diet analysis of gray seals in US waters showed a significant disparity of prey items among the age groups, which suggests that seals gain foraging experience as they mature (Ampela 2009). Naïve weanlings are not adequately developed physiologically to access foraging areas off-shore or at greater depths where older or larger animals may find the proper types and amounts of prey items (Burns 1999, Noren et al. 2005, Beck et al. 2007, Ampela 2009, Breed et al. 2009, Bennett et al. 2010). If proper nutrients are not obtained through diet, this can directly impact the body's ability to sustain hair growth (Rushton 2002) or indirectly increase susceptibility to infectious disease (Trites \& Donnelly 2003). Juvenile Australian fur seals Arctocephalus pusillus with partial alopecia had significantly lower concentrations of zinc and tyrosine in their fur compared to unaffected individuals (Lynch et al. 2012). The authors described breakage in the hair shaft and suggested reduced hair strength was caused by low zinc content. Investigation into variation in diet and foraging areas was suggested by Lynch et al. (2012). Similarly, investigation into the nutritional value of prey items and analysis of hair samples for amino acid and mineral composition in juvenile gray seals with and without alopecia is warranted.

\section{A seasonal association}

Alopecia was most prevalent during the warm months of late spring and summer which were characterized by seasonal shifts in environmental temperature and gray seal group behavior dynamics. Pathogens, such as fungal, bacterial, parasitic, or viral agents often thrive in warmer environments (Poulin 2006, Burek et al. 2008, Tryland et al. 2009). In some pinniped species, the onset of alopecia and fungal dermatitis was attributed to abnormally warm water temperatures (Higgins 2000). During the late spring and summer there is an increase in gray seal population density and a mixing of age classes at haul-out sites. The combination of persistence of an infectious agent in a warmer environment and increased density at haul-out sites may create an optimal situation for disease transmission to a more susceptible age class (Lavigne \& Schmitz 1990, Duignan et al. 1995).

Not only can overcrowding increase the opportunity for disease transmission, the seasonal increase in gray seal density may also lead to increased stress through intraspecific competition for space and food. Additionally, seals are not the only taxon that congregate in high numbers around Cape Cod during the spring and summer months. The human population grows exponentially as well, resulting in increased human activity close to haul-out sites and foraging areas causing limitations to where seals can carry out normal behavior (i.e. resting and feeding). Chronic stress has multiple negative effects on the overall health of many wild, domesticated, and laboratory animals (Novak \& Meyer 2009, Novak et al. 2014) and was suspected to be a factor in the recent increase in observations of alopecia in polar bears (Bowen et al. 2015). The comparison of stress hormones in weanlings with and without hair loss throughout all season would help explain if seasonal peaks in environmental stressors are a contributor to the onset of alopecia.

\section{Increase over time may correlate to changes in environment}

The occurrence of alopecia in gray seals increased considerably over the $10 \mathrm{yr}$ time frame of this study. During that same period, there have been notable changes within the immediate environment of the gray seals in Massachusetts. The Gulf of Maine was recently declared as the fastest warming body of water on the planet (Pershing et al. 2015, Saba et al. 2016). With warming water comes changes in marine 
chemistry, such as salinity and $\mathrm{pH}$, which may indirectly impact gray seals through long-term shifts in prey availability (Learmonth et al. 2006, Burek et al. 2008, Nye et al. 2009) and subsequent changes in nutrition needed to sustain a healthy pelage. Climate change has also been linked to increased incidences of emerging or resurging infectious disease outbreaks among wildlife (Harvell et al. 1999, Daszak et al. 2001, Burek et al. 2008). In particular, warmer environments have been suspected to influence many infectious disease mass mortalities in pinnipeds globally (Lavigne \& Schmitz 1990, Kuiken et al. 2006). The emerging enzootic alopecia disease observed in Massachusetts grays seals could be potentially instigated and sustained by the increase in environmental temperatures.

Over the past 3 decades, the northeast US experienced a significant increase in human population growth and land usage along coastal communities, with Massachusetts being one of the leading states in coastal population density (Crossett et al. 2004). Human encroachment on natural environments often has a detrimental effect on wildlife through habitat loss and industrial and agricultural contaminant runoff into marine ecosystems (McKee et al. 2004, Bradley \& Altizer 2007, Veron et al. 2009). Exposure to contaminants, specifically endocrine disruptors, alters hair growth and cell signaling pathways that could impact the hair growth cycle and incite inflammatory responses (Bergman et al. 2003, Gregory \& Cyr 2003, Novak \& Meyer 2009). Observations of alopecia have been linked to contaminant-induced hyperadrenocorticism in Baltic gray seals (Bergman et al. 2003) and high levels of heavy metals and persistent organic pollutants in Australian fur seals (Lynch et al. 2012). On a more local level, high levels of perfluorochemicals (PFCs) have been measured from the liver of northwest Atlantic harbor seals Phoca vitulina with $<1 \mathrm{yr}$ olds having 2.6-fold higher concentration than adult females (Shaw et al. 2009). Gray seals were not included in that study nor was a correlation with alopecia made. However, overlap of habitat usage of the 2 pinniped species is evident throughout the Gulf of Maine. Therefore, it is possible that similar levels of PFCs could be found in northwest Atlantic gray seals. The parallel increase of human coastal usage in Massachusetts and the occurrence of alopecia in gray seals must be recognized and investigated.

The etiology of alopecia in gray seals in Massachusetts is currently unknown but is likely very complex, involving the interplay of multiple factors. It appears to be a significant emerging condition that could signal underlying health concerns of an individual and possibly the local population. Marine mammals are considered sentinels of the ocean (Moore 2008, Bossart 2011, Simeone et al. 2015), thus any emerging disease condition should be considered in parallel with ecosystem health. Being semi-aquatic, phocids are often the direct link between humans and oceans due to their overlap in habitat and resource use. The cause of alopecia within the gray seal population of Massachusetts could potentially pose concern to human health, particularly if the etiology is zoonotic in nature or attributed to endocrine disruptors found within environments or prey items utilized by humans. Continued documentation of alopecia prevalence among gray seals and methodical investigation into the etiology of the condition is warranted.

Acknowledgements. All stranding response was authorized through Stranding Agreements between the National Oceanic and Atmospheric Administration (NOAA), Greater Atlantic Region Fisheries Office (GARFO) and the New England Aquarium (NEAQ) and NOAA GARFO and the International Fund for Animal Welfare (IFAW). Partial funding for marine mammal stranding response was provided to NEAQ and IFAW through support from the NOAA John H. Prescott Marine Mammal Program. NEAQ grant numbers: NA03NMF4390406, NA06NMF4390154, NA07NMF4390220, NA08NMF4390565, and NA10NMF4390231. IFAW grant numbers: NA11NMF4390078, NA11NMF4390079, and NA10NMF4390245. All images of seal haul-out sites were taken by Center for Coastal Studies (CCS) under the Northeast Fisheries Science Center Permit Number 17670. Seal haulout survey work was supported by the Elinor Patterson Baker Trust and the Mandel-Rodis Fund. We thank the numerous staff from NEAQ, IFAW, and CCS who were involved in marine mammal stranding response and survey efforts over the $10 \mathrm{yr}$ span of this study. Volunteers and interns are essential to marine mammal stranding response and efforts to collect the wealth of data would not have been possible without them. The map in Fig. 4 was created by Erinn Hasselgren.

\section{LITERATURE CITED}

Ampela K (2009) The diet and foraging ecology of gray seals (Halichoerus grypus) in United States waters. PhD thesis, City University of New York, Staten Island, NY

Andrews JC, Mott PR (1967) Grey seals at Nantucket. J Mammal 48:657-658

* Atwood T, Peacock E, Burek-Huntington K, ShearnBochsler V, Bodenstein B, Beckmen K, Durner G (2015) Prevalence and spatio-temporal variation of an alopecia syndrome in polar bears. J Wildl Dis 51:48-59

* Barnett JE, Davison NJ, Thornton SM, Riley P, Cooper T, Wessels ME (2011) Systemic mucormycosis in a hooded seal (Cystophora cristata). J Zoo Wildl Med 42:338-341

Beck CA, Iverson SJ, Bowen WD, Blanchard W (2007) Sex differences in grey seal diet reflect seasonal variation in foraging behaviour and reproductive expenditure: evidence from quantitative fatty acid signature analysis. J Anim Ecol 76:490-502 
Bello-Gutiérrez J, Suzán G, Hidalgo-Mihart MG, Salas G (2010) Alopecia in bats from Tabasco, Mexico. J Wildl Dis 46:1000-1004

Bennett KA, Mcconnell BJ, Moss SEW, Speakman JR, Pomeroy PP, Fedak MA (2010) Effects of age and body mass on development of diving capabilities of gray seal pups: costs and benefits of the postweaning fast. Physiol Biochem Zool 83:911-923

Bergman A, Bignert A, Olson ME (2003) Pathology in Baltic grey seals (Halichoerus grypus) in relation to environmental exposure to endocrine disruptors. In: Vos JG, Bossart GD, Fournier M, O'Shea TJ (eds) Toxicology of marine mammals. CRC Press, New York, NY, p 507-533

Bildfell RJ, Mertins JW, Mortenson JA, Cottam DF (2004) Hair-loss syndrome in black-tailed deer of the Pacific Northwest. J Wildl Dis 40:670-681

* Bogomolni AL, Pugliares KR, Sharp SM, Patchett K and others (2010) Mortality trends of stranded marine mammals on Cape Cod and southeastern Massachusetts, USA, 2000 to 2006. Dis Aquat Org 88:143-155

Boily P, Lavigne D (1996) Thermoregulation of juvenile grey seals, Halichoerus grypus, in air. Can J Zool 74:201-208

* Bossart GD (2011) Marine mammals as sentinel species for oceans and human health. Vet Pathol 48:676-690

Bowen WD, McMillan J, Mohn R (2003) Sustained exponential population growth of grey seals at Sable Island, Nova Scotia. ICES J Mar Sci 3139:1352-1360

*Bowen WD, Iverson SJ, McMillan JI, Boness DJ (2006) Reproductive performance in grey seals: age-related improvement and senescence in a capital breeder. J Anim Ecol 75:1340-1351

* Bowen L, Miles AK, Stott J, Waters S, Atwood T (2015) Enhanced biological processes associated with alopecia in polar bears (Ursus maritimus). Sci Total Environ 529: 114-120

Bradley CA, Altizer S (2007) Urbanization and the ecology of wildlife diseases. Trends Ecol Evol 22:95-102

Breed GA, Jonson ID, Myers RA, Bowen WD, Leonard ML (2009) Sex-specific, seasonal foraging tactics of adult gray seals (Halichoerus grypus) are revealed by statespace analysis. Ecology 90:3209-3221

* Burek KA, Gulland FMD, O'Hara TM (2008) Effects of climate change on Arctic marine mammal health. Ecol Appl 18(Suppl):S126-S134

* Burns JM (1999) The development of diving behavior in juvenile Weddell seals: pushing physiological limits in order to survive. Can J Zool 77:737-747

Costa DP, Kooyman GL (1982) Oxygen consumption, thermoregulation and effects of fur oiling and washing on the sea otter. Can J Zool 60:2761-2767

* Costello CM, Quigley KS, Jones DE, Inman RM, Inman KH (2006) Observations of a denning-related dermatitis in American black bears. Ursus 17:186-190

Crossett KM, Culliton TJ, Wiley PC, Goodspeed TR (2004) Population trends along the coastal United States: 19802008. Coastal Trends Report Series. NOAA's National Ocean Service Management and Budget Office Special Projects

Daszak P, Cunningham AA, Hyatt AD (2001) Anthropogenic environmental change and the emergence of infectious diseases in wildlife. Acta Trop 78:103-116

Duignan PJ, Saliki JT, St Aubin DJ, Early G and others (1995) Epizootiology of morbillivirus infection in North American harbor seals (Phoca vitulina) and gray seals (Halichoerus grypus). J Wildl Dis 31:491-501
Duignan PJ, Oise MF, Bressem V, Baker JD and others (2014) Phocine distemper virus: current knowledge and future directions. Viruses 6:5093-5134

Frank A (1998) Mysterious moose disease in Sweden. Similarities to copper deficiency and/or molybdenosis in cattle and sheep. Biochemical background of clinical signs and organ lesions. Sci Total Environ 209:17-26

Gregory M, Cyr DG (2003) Effects of environmental contaminants on the endocrine system of marine mammals. In: Vos JG, Bossart GD, Fournier M, O'Shea TJ (eds) Toxicology of marine mammals. CRC Press, New York, NY, p 67-81

*Hammill MO, Gosselin JF (1995) Grey seal (Halichoerus grypus) from the Northwest Atlantic: female reproductive rates, age at first birth, and age of maturity in males. Can J Fish Aquat Sci 52:2757-2761

Harvell CD, Kim K, Burkholder JM, Colwell RR and others (1999) Emerging marine diseases: climate links and anthropogenic factors. Science 285:1505-1510

* Higgins R (2000) Bacteria and fungi of marine mammals: a review. Can Vet J 41:105-116

Izdebska JN, Rolbiecki L (2010) Parasitic arthropods as the cause of parasitoses in aquatic animals. In: Buczek A, Blaszak C (eds) Arthropods. Ecological and pathological aspects of parasite-host relationships. Akapit, Lubin, p 125-135

Jensen-Jarolim E, Einhorn L, Herrmann I, Thalhammer JG, Panakova L (2015) Pollen allergies in humans and their dogs, cats and horses: differences and similarities. Clin Transl Allergy 5:15

* Kennedy-Stoskopf S, Stoskopf MK, Eckhaus MA, Strandberg JD (1986) Isolation of a retrovirus and a herpesvirus from a captive California sea lion. J Wildl Dis 22:156-164

Kovacs K, Lavigne DM (1986) Growth of grey seal (Halichoerus grypus) neonates: differential maternal investment in the sexes. Can J Zool 64:1937-1943

K Kuiken T, Kennedy S, Barrett T, Van de Bildt MWG and others (2006) The 2000 canine distemper epidemic in Caspian seals (Phoca caspica): pathology and analysis of contributory factors. Vet Pathol 43:321-338

* Kvadsheim PH, Aarseth JJ (2002) Thermal function of phocid seal fur. Mar Mamm Sci 18:952-962

*avigne DM, Schmitz OJ (1990) Global warming and increasing population densities: a prescription for seal plagues. Mar Pollut Bull 21:280-284

Learmonth JA, MacLeod CD, Santos MB, Pierce GJ, Robinson RA (2006) Potential effects of climate change on marine mammals. Oceanogr Mar Biol Annu Rev 44:431-464

Lelli B, Harris DE, Aboueissa AM (2009) Seal bounties in Maine and Massachusetts, 1888 to 1962. Northeast Nat (Steuben) 16:239-254

*Lipscomb TP, Mense MG, Habecker PL, Taubenberger JK, Schoelkopf R (2001) Morbilliviral dermatitis in seals. Vet Pathol 38:724-726

* Liwanag HEM, Berta A, Costa DP, Budge SM, Williams TM (2012) Morphological and thermal properties of mammalian insulation: the evolutionary transition to blubber in pinnipeds. Biol J Linn Soc 107:774-787

* Lynch M, Kirkwood R, Mitchell A, Duignan P, Arnould JPY (2011) Prevalence and significance of an alopecia syndrome in Australian fur seals (Arctocephalus pusillus doriferus). J Mammal 92:342-351

Kynch M, Kirkwood R, Gray R, Robson D and others (2012) Characterization and causal investigations of an alopecia syndrome in Australian fur seals (Arctocephalus pusillus doriferus). J Mammal 93:504-513 
Madslien K, Ytrehus B, Vikøren T, Malmsten J, Isaksen K, Hygen HO, Soldberg EJ (2011) Hair-loss epizootic in moose (Alces alces) associated with massive deer ked (Lipoptena cervi) infestation. J Wildl Dis 47: 893-906

Mannan MA, Khan R, Rahman MM, Begum F, Uddin MZ (2009) Isolation and identification of dermatophilus bacteria from the skin lesions of cattle. Bangl J Vet Med 7: 342-347

McKee JK, Sciulli PW, Fooce CD, Waite TA (2004) Forecasting global biodiversity threats associated with human population growth. Biol Conserv 115:161-164

McLaren IA (1993) Growth in pinnipeds. Biol Rev Camb Philos Soc 68:1-79

Moore SE (2008) Marine mammals as ecosystem sentinels. J Mammal 89:534-540

Murie DJ, Lavigne DM (1992) Growth and feeding habits of grey seals (Halichoerus grypus) in the northwestern Gulf of St. Lawrence, Canada. Can J Zool 70:1604-1613

Noren SR, Iverson SJ, Boness DJ (2005) Development of the blood and muscle oxygen stores in gray seals (Halichoerus grypus): implications for juvenile diving capacity and the necessity of a terrestrial postweaning fast. Physiol Biochem Zool 78:482-490

Noren SR, Boness DJ, Iverson SJ, McMillan J, Bowen WD (2008) Body condition at weaning affects the duration of the postweaning fast in gray seal pups (Halichoerus grypus). Physiol Biochem Zool 81:269-277

Novak MA, Meyer JS (2009) Alopecia: possible causes and treatments, particularly in captive nonhuman primates. Comp Med 59:18-26

Novak MA, Hamel AF, Coleman K, Lutz CK and others (2014) Hair loss and hypothalamic-pituitary-adrenocortical axis activity in captive rhesus macaques (Macaca mulatta). J Am Assoc Lab Anim Sci 53:261-266

Nye JA, Link JS, Hare JA, Overholtz WJ (2009) Changing spatial distribution of fish stocks in relation to climate and population size on the Northeast United States continental shelf. Mar Ecol Prog Ser 393:111-129

Pedersen SC, Popowics TE, Kwiecinski GG, Knudsen DEB (2012) Sublethal pathology in bats associated with stress and volcanic activity on Montserrat, West Indies. J Mammal 93:1380-1392

Pershing AJ, Alexander MA, Hernandez CM, Kerr LA and others (2015) Slow adaptation in the face of rapid warming leads to collapse of the Gulf of Maine cod fishery. Science 350:809-812

Pier AC, Cabañes FJ, Chermette R, Ferreiro L, Guillot J, Jensen HE, Santurio JM (2000) Prominent animal mycoses from various regions of the world. Med Mycol 38(Suppl 1):47-58

Poulin R (2006) Global warming and temperature-mediated increases in cercarial emergence in trematode parasites. Parasitology 132:143-151

Reeves RR, Stewart B, Clapham P, Powell J (2002) Pinnipeds. In: National Audubon Society guide to marine mammals of the world. Alfred A Knopf, New York, NY, p 138-141

Editorial responsibility: Stephen Raverty, Abbotsford, British Columbia, Canada
Rosen DAS, Winship AJ, Hoopes LA (2007) Thermal and digestive constraints to foraging behaviour in marine mammals. Philos Trans R Soc Lond B Biol Sci 362: 2151-2168

Rough V (1995) Gray seals in Nantucket Sound, Massachusetts, winter and spring, 1994. Final report to US Marine Mammal Commission, Contract T10155615. National Technical Information Service Publication PB95-191391, Marine Mammal Commission, Bethesda, MD

Rushton DH (2002) Nutritional factors and hair loss. Clin Exp Dermatol 27:396-404

* Saba VS, Griffies SM, Anderson WG, Winton M and others (2016) Enhanced warming of the Northwest Atlantic Ocean under climate change. J Geophys Res Oceans 121:118-132

Shaw S, Berger ML, Brenner D, Tao L, Wu Q, Kannan K (2009) Specific accumulation of perfluorochemicals in harbor seals (Phoca vitulina concolor) from the northwest Atlantic. Chemosphere 74:1037-1043

Simeone CA, Gulland FM, Norris T, Rowles TK (2015) A systematic review of changes in marine mammal health in North America, 1972-2012: the need for a novel integrated approach. PLOS ONE 10:e0142105

Tang ZH, Zhang GL, Sheng LX, Hong TY and others (2012) Alopecia in Rickett's big-footed bat Myotis ricketti (Chiroptera: Vespertilionidae) in relation to age and sex. Zool Stud 51:494-499

Thompson PM, Corpe HM, Reid RJ (1998) Prevalence and intensity of the ectoparasite Echinophthirius horridus on harbour seals (Phoca vitulina): effects of host age and inter-annual variability in host food availability. Parasitology 117:393-403

*Trites AW, Donnelly CP (2003) The decline of Steller sea lions Eumetopias jubatus in Alaska: a review of the nutritional stress hypothesis. Mammal Rev 33:3-28

Tryland M, Godfroid J, Arneberg P (eds) (2009) Impact of climate change on infectious diseases of animals in the Norwegian Arctic. Kortrapport/Brief Report Series 10. Norsk Polarinstitut, Tromsø

V Veron JEN, Hoegh-Guldberg O, Lenton TM, Lough JM and others (2009) The coral reef crisis: the critical importance of <350 ppm $\mathrm{CO}_{2}$. Mar Pollut Bull 58:1428-1436

Waring GT, Josephson E, Maze-Foley K, Rosel PE (2016) US Atlantic and Gulf of Mexico marine mammal stock assessments-2015. NOAA Technical Memorandum NMFSNE-238

*Watts P, Hansen S, Lavigne DM (1993) Models of heat loss by marine mammals. J Theor Biol 163:505-525

Wood SA, Brault S, Gilbert JR (2007) 2002 aerial surveys of grey seals in the northeastern United States. NAMMCO Sci Publ 6:117-121

Wood SA, Frasier TR, McLeod BA, Gilbert JR and others (2011) The genetics of recolonization: an analysis of the stock structure of grey seals (Halichoerus grypus) in the Northwest Atlantic. Can J Zool 89:490-497

Zaiontz C (2015) Real statistics using Excel. www.real-statistics.com

Submitted: February 12, 2018; Accepted: September 13, 2018 Proofs received from author(s): November 7, 2018 